\title{
Theoretical analysis of state capture and its manifestation as a governance problem in South Africa
}

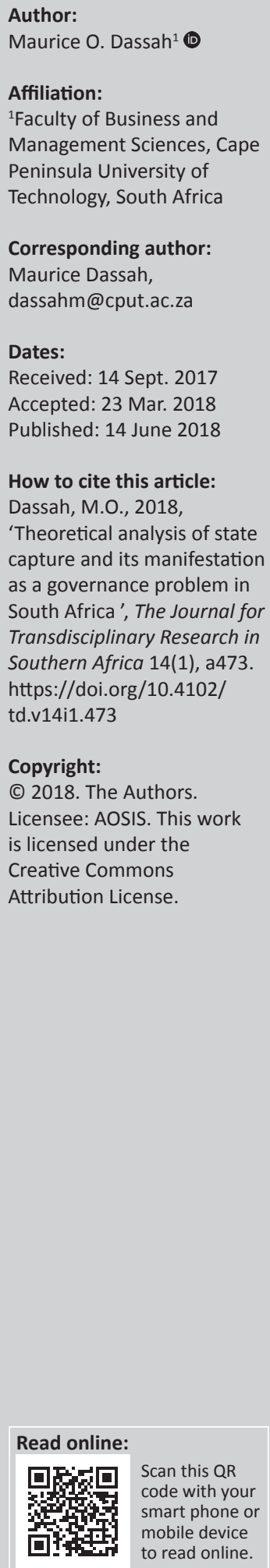

\begin{abstract}
State capture became topical in South Africa in March 2016 following the dismissal of the then Minister of Finance, Nhlanhla Nene, on 09 December 2015. 'Nenegate' revealed poor understanding of state capture among politicians and the general public. The literature indicates that state capture lacks analytical clarity as there is no clear demarcation between legitimate political lobbying and state capture created by corruption. The research question addressed in this article is: What is state capture and how is it manifested in South Africa? Firstly, it systematically unpacks the phenomenon as a type of business-state relationship distinct from influence, corruption and lobbying and outlines its types, features and essence. Secondly, the article explores state capture in contemporary South Africa. Methodology-wise, a combination of literature study and current research reports is used to illuminate the phenomenon and its manifestation. The article contributes to existing knowledge by not only clarifying a concept conflated with corruption but also analysing the manifestations of state capture in South Africa.
\end{abstract}

\section{Introduction}

The phenomenon of state capture was identified at the dawn of the new millennium (Hellman, Jones \& Kaufmann 2000a) as an aberration in governance, but gained topicality in South African political discourse in March 2016. On national television, then Deputy Minister of Finance, Mcebisi Jonas, said the Gupta brothers, who are not only friends of the President but also business partners of his son, had allegedly offered him the position of Minister of Finance before the then incumbent, Nhlanhla Nene, was dismissed on 09 December 2015 and replaced by Des van Rooyen. However, mounting pressure compelled the President to replace Des van Rooyen with Pravin Gordhan. Nhlanhla Nene's dismissal fuelled speculation that the President's prerogative of appointing and removing ministers is usurped by the Gupta brothers. Then Public Protector, Advocate Thuli Madonsela, received and investigated various complaints, including possible violation of the Executive Members' Ethics Act (1998) regarding appointment of cabinet ministers, directors and awarding of state contracts to businesses associated with the Gupta brothers. In a major twist, Pravin Gordhan and Mcebisi Jonas were removed as Minister of Finance and Deputy Minister in a major cabinet reshuffle on 30 April 2017 and replaced by Malusi Gigaba and Sfiso Buthelezi, respectively. The 'Nenegate' furore of March 2016 revealed a lack of understanding of state capture among politicians and the general public, with one politician stating that because the state consists of three organs, state capture cannot occur unless all three are captured.

This article, which is based on literature study and analysis of research reports, discusses theoretical and practical aspects of state capture through the research question: What is state capture and how is it manifested in South Africa? It is structured in two parts, the first of which unpacks theoretical aspects in a literature review that defines the phenomenon and uncovers its origin; outlines its theoretical basis and competing ideologies; distinguishes among corruption, influence and lobbying; and highlights its types, features and essence. Part two discusses state capture in South Africa by highlighting key observations made on investigative issues in the Public Protector's 'State of Capture Report', discussing critical points in the 'State Capacity Research Project Report', including captor actors, how they are organised and their various roles in the patronage network, methods or modalities of capture and areas or targets of capture. The article also highlights issues in the South African Council of Churches' (SACC's) 'Unburdening Panel Process Report'. 


\section{Literature review Origin of state capture and definition}

The phenomenon of state capture was first observed by Hellman et al. (2000a) who conducted the first Business Environment and Enterprise Performance Survey in 1999 on behalf of the World Bank and European Bank for Reconstruction and Development. Hellman and colleagues used the term 'state capture' to describe a new dimension corruption had taken in East European countries (Richter n.d.:2) moving from planned to market economy. 'State capture' was coined and used in referring to the existence of three grand corruption aspects among political and business elites in the former communist countries of Eastern Europe, which involved 'payment of bribes to gain contracts but also the purchase of political influence' (Hall 2012:4). The phenomenon derives from the notion of regulatory capture (Wren-Lewis 2011:148), which is about a problematic relationship between the regulator and 'special interests', the regulated. Similarly, state capture is about a problematic relationship between politics and business in the context of transition and rooted in the market for influence (Hellman n.d.:n.p.).

State capture is an aberration in governance. The literature is replete with a plethora of definitions, one of the earliest being: 'efforts of firms to shape the laws, policies, and regulations of the state to their own advantage by providing illicit private gains to public officials' (Hellman \& Kaufmann 2001:1). Hellman et al. (2000c:4) provide the following definition: 'the propensity of firms to shape the underlying rules of the game by "purchasing" decrees, legislation, and influence', or 'efforts of firms to shape and influence the underlying rules of the game (i.e. legislation, laws, rules, and decrees) through private payments to public officials'. These definitions focus on firms, but omit an important agent or captor actor (individuals in private or official capacity) and a critical means of capture (funding of political activities). Consequently, the operating definition of state capture (Transparency International 2014) in this article is,

\begin{abstract}
... one of the most pervasive forms of corruption, where companies, institutions or powerful individuals use corruption such as the buying of laws, amendments, decrees or sentences, as well as illegal contributions to political parties and candidates, to influence and shape a country's policy, legal environment and economy to their own interests. (p. 1)
\end{abstract}

By seizing of laws to the advantage of corporate business via influential political links in the parliament and government (Pesic 2007:1), the legal system is rendered the opposite of what it should be as it serves illegal interests disguised in legal form.

'Capture' is a military metaphor invested with connotation of force used by individuals or business entities to hold the state to ransom, but the capture process is, in fact, informal, subtle, covert or surreptitious in nature, not overt or characterised by violence. Adams et al. (2007:1) note that although 'capture' may conjure images of physical capture, the process is more of capturing 'hearts, minds and emotions'. It is the process of making laws, policies and regulations individuals or business entities seek to influence, not implementation of existing laws. As such, state capture involves subversion of public interest. In state capture situations, the nature of the business entity-state relationship is illicit, which implies that laws and regulations made or actions taken are products of corrupt acts or transactions. Consequently, legality becomes a function of illegality. Although captors are typically private sector individuals or business entities, public officials themselves are capable of capturing state institutions. An example is Vladimo Montesinos Lenin, who was head of Peru's intelligence services under President Alberto Fujimori (1990-2000). He first captured the media and key agencies such as the judiciary and military (Kupferschmidt 2009:14). Thereafter, he used the military as an instrument to facilitate arms and narcotics trafficking and the tax authority to finance illicit activities and compel unwilling individuals to cooperate. Private gain by individuals or business entities at the expense of the public, and in fact, subversion of public interest is the primary motive of state capture.

\section{State capture theory and ideologies}

Stigler's (1971) 'Theory of Economic Regulation', referred to as 'capture theory', attributes difficulty in implementing socio-economic development in former socialist countries to negative short-term welfare effects of economic reforms. Hellman et al. (2000b) overturned this view by arguing that criminal capture of state organs and policy formulation itself by politico-economic elite networks presents the main obstacle to progressive societal reorganisation, thereby establishing current state capture theory.

The notion of state capture is ideologically contested. There are three schools of thought, the neo-liberal, neo-institutional economics and Marxists, each with different notions of the state and economic, political and ideological understandings of state capture. The neo-liberal perspective of state capture, which currently holds sway, is propagated by the World Bank and other international financial institutions. For neoliberals, state capture occurs because policymakers are inherently corrupt and use state power for rent allocation and patronage (Robison \& Hadiz 2004:4). Neo-liberals believe in self-regulation, the economic assumption underpinning their view of state capture being that the forces of demand and supply are better determinants of interest and exchange rates, ensuring availability of capital through savings. Rentseeking and capture of economic policy by policymakers militate against efficient allocation of savings and investments, thereby hampering economic development (Srouji 2005:13).

New institutional economists believe in intervention of state institutions to address market failure and are opposed to neo-liberals. For them, institutions ensure efficiency and play the important role of reducing transaction costs (Srouji 2005:14). State capture occurs when institutions are weak or 
not independent enough to enforce rules. Based on this view, there are two types of capture. The first is that orchestrated by lobby and private sector groups or distributional coalitions motivated by their own interests to manipulate policy in order to increase their share of national income (Haggard 1985:509). The second and more extreme type of state capture sees policymakers and rent seekers groups as having the common aim of extracting as much as they can from society, while maintaining their power base (Bardhan 2001:255; Evans 1985). According to new institutional economists, different kinds of states and institutions of different natures exist. For them, a 'strong' state with minimal government authority ('monopoly of violence') able to enforce property and contractual rights or a developmental state with an independent professional bureaucracy is the ideal. Neither the neo-liberalist nor new institutional economists' view adequately explains the co-existence of bureaucrats and private sector actors in the successful tiger economies of East Asia, or how policies benefit some societal groups and the national economy simultaneously (Srouji 2005:15).

Marxists believe the state is always under the control of a dominant group, class or coalition, that is, the state is viewed as serving the interests of groups, classes or coalitions. Effectively then, the state is under perpetual capture (Srouji 2005:16). There are two Marxist views on state capture. The Gramcians see the state as a force for cohesion, not an instrument of domination, while other Marxists view the state as an instrument in the hands of a dominant group, especially where capitalists hold political power. For them, state capture occurs because of an ongoing struggle between different capitalists to influence economic and social policy within state institutions. This leads to a number of outcomes such as parliament making rules to ensure capitalists accumulate wealth and capitalists manipulating the state for continuous profits and seeking to sustain power by creating disunity among workers (Srouji 2005:17).

\section{Distinguishing state capture from corruption, influence and lobbying}

State capture is an aspect of systemic political corruption implicated in causing poor governance (Sitorus 2011:46) in transitional democracies, with the potential of aggravating developmental problems. Corruption, a governance problem globally, is a versatile umbrella concept with family resemblance to clientelism, patronage, particularism, patrimonialism and state capture, which is the most recent, but most harmful (Varraich 2014:26). Developed by Ludwig Wittgenstein, family resemblance is defined as (Varraich 2014):

[...] a category, defined in a particular way that may fit a number of cases reasonably well, but on close examination it can become clear that for most cases the fit is not perfect. (p. 3)

Clientelism, patronage, particularism and patrimonialism focus on the output side of corruption, while state capture focuses directly on the input side (Varraich 2014:25) and can shift corruption from the illegal domain to the legal and distort the intended effects of laws and policies. As state capture is concerned with the decision-making sphere, where laws and policies are made and implemented based on interests, it falls into the category of political or grand corruption (Santos 2011:23).

\section{Corruption}

According to Sitorus (2011:47), the key distinction between corruption and state capture is that most types of corruption aim to subvert the implementation of laws, rules and regulations through acts of bribery, while state capture involves corrupt attempts to influence the way laws, rules and regulations are formed, making it synonymous with legalised corruption. Although state corruption and state capture are linked, the latter is not simply widespread corruption, but essentially 'a distinct network structure in which corrupt actors cluster around certain state organs and functions' (Fazekas \& Tóth 2014:3).

Although state capture is an aspect of corruption, it is not synonymous with grand corruption. The former refers to individuals or entities surreptitiously influencing the lawmaking process in order to shape formation of the basic rules of the game, whereas grand corruption involves subverting existing rules of the game governing awarding of contracts and implementation of laws (Ouzounov 2004:1191). However, some forms of grand corruption, such as buying votes of members of parliament, bribing government officials or bribing judges to influence their decisions, have the overall effect of conferring undue advantages to firms within a country's legal and regulatory framework and constitute state capture (Hellman \& Kaufmann 2001:n.p.). Another difference between state capture and corruption is that policy outcomes are not certain in the case of corruption, but known to be beneficial to captors in the case of state capture.

\section{Influence}

Influence is the capacity to have an impact on shaping and affecting the form or content of the basic rules of the game without having to pay public officials or politicians (Hellman et al. 2000a:n.p.). However, firms may seek to shape and influence legislation, laws, rules and decrees through payments or 'capture' influential individuals through formation of close relationships. Hellman et al. (2000a [summary findings]) state that influence is inherited as a legacy by large, established or incumbent firms with ties to the state, which provides them with greater security of property and contractual rights. However, according to the authors, new firms seeking influence have to buy advantages or benefits where there are formidable entry barriers or strong competition, the implication being that new firms are more likely than incumbent firms to be 'captors'. Irrespective of the type of political system, firms and groups compete against each other for influence (Hellman n.d.):

$[\ldots]$ over the state to have an impact on the choice and design of laws, rules and regulations in order to shape these rules of the game to their own advantage. (n.p.) 
In this way, they create favourable conditions for themselves within a country's institutional framework. Influence is not inherently bad. However, a highly segmented market for influence provides fertile grounds for various kinds of distortions, including illicit acts (Hellman n.d.:n.p.).

\section{Lobbying}

State capture is an illegal activity, while lobbying is a legally acceptable practice. Lobbying or 'representation of group concerns in a political discourse in search for the greater public good' (Ricther, n.d.:9) is also different from clientelism, the protection of private interests by money or force which, together with patronage, provide a platform for institutions such as parliaments in fledgling, post-conflict democratic states to be holistically captured through the making of laws. Lobbying is mainly targeted at policymaking institutions, rather than the bureaucracy (Campo \& Giovannoni 2006:1). It is defined as 'strategic influence exerted on a (sic) public policies and its formulation in line with the partial interests of some group or an individual' (Begovi 2005:5). State capture, corruption and lobbying are all methods of rent-seeking. Lobbying results in state capture and misallocation of resources (Begovi 2005:4). The difference between lobbying and corruption is based on jurisprudence, which varies among countries. Although sharing expert advice with policymakers is clearly lobbying, another form of exerting influence such as direct financing of election campaigns by business might be lobbying in some countries and corruption in others. Lobbying is done publicly and transparency is its distinguishing feature, setting it apart from both corruption and state capture, which are surreptitious. Lobbying can be a substitute for or a complement to corruption because it 'can be both an activity that makes bribing irrelevant if it succeeds in influencing policy and an activity that makes bribing easier if it succeeds in undermining law enforcement' (Campo \& Giovannoni 2006:1). Further, evidence suggests lobbying is a more effective way of exerting influence than corruption (Campo \& Giovannoni 2006:3) and more likely to be used by larger firms from developed countries than smaller ones in developing countries (Campo \& Giovannoni 2006:15).

\section{Types of state capture}

According to Sitorus (2011:47), two types of state capture can be distinguished. The first relates to distinguishing among types of institutions that can be captured, which include legislative, executive, judicial, regulatory agencies and public works departments or ministries. Richter (n.d.:8) states that although all types of state institutions are susceptible to capture by private actors, 'the most important ones are where political decisions are made' such as the legislature and the executive.

The second distinction has to do with types of captors seeking to capture the state, which include large private firms, political leaders, high-ranking officials or interest groups. Fazekas and Tóth (2014:5) present a third type by distinguishing between the capture of a single organisation or government department (local capture) and capture of all organisations or government departments (global capture). Local capture occurs when 'only some public and private organisations enter into a capture relationship with their "islands" relatively autonomous' (Fazekas \& Tóth 2014:5). In global capture, 'captured organisations are linked to each other and a national level elite controls them' (Fazekas \& Tóth 2014:3).

In distinguishing between party state capture and corporate state capture, Innes (2013:1) provides a fourth dimension on types. Party state capture refers to re-politicisation of the state by political parties to achieve political monopoly, while corporate state capture is exercise of power by private interests to subvert legitimate channels of political influence mainly for private gain.

The fifth type of capture relates to systemic or predatory capture (Mtimka 2016:n.p.). Systemic state capture refers to the impact institutions have on a state's internal and external sovereignty, thereby preventing it from pursuing policies of its choice other than those beneficial to powerful interests or sectors. In systemic state capture, more often than not, no single captor or beneficiary can be credited with being instrumental in the capture. Predatory state capture occurs when individuals or small groups 'hold specific political figures ransom' and bully them for personal gain (Mtimka 2016:n.p.).

ANC Today (25 May 2016) outlines a typology of three types of captured states. The occasionally captured is characterised by occasional deviations that benefit private interests and public officials. The partially captured state 'is when there are high averages of corrupt contracts and activities but this is not the norm and the state is in the main focused on achieving its developmental objectives', while a fully captured state 'is when high levels of corruption directed by the dominant private interest represents the norm, and the developmental agenda is subordinated to corrupt exchanges'.

\section{Features and essence of state capture}

Richter (n.d.:8-9) outlines four key features of state capture. Firstly, individuals or business entities with an agenda to capture state institutions or people in positions of power tend to focus on the political level of elected and unelected officials as captives because they are responsible for making policy decisions and laws, not on bureaucrats in the administrative stratum who implement policies and laws. Secondly, it is network-based like corruption, which thrives on social and political networks through clientelism and patronage (Richter n.d.:8). Networks are based on informal rules among members established on the basis of authority-dominance or reciprocity-loyalty, which open the avenue for involvement of private, state or non-state and interest groups in the making of rules, some of which may not be participants in corrupt behaviour. Thirdly, unlike corruption, achievement 
of private gain is not the primary motive for illegitimate behaviour. This means, while politicians and officials may be motivated by monetary gains, their overriding consideration is the 'quest to gain access to power or stay in power' (Richter n.d.:8). In fact, in countries where capture is deeply entrenched, monetary transactions are subordinated to intimidation, protection and occasional violence (Philp 2008:9). Fourthly, camouflage or use of formal institutions to represent their interest is the stock-in-trade of informal networks. Participation of various interest groups, citizens and civil society as well as the involvement of the media and political parties is essential for democracy, but the media and political parties may, consciously or inadvertently, serve as intermediaries for powerful, private actors.

Hall (2012:4) outlines three key features of state capture, namely involvement of systematic networks and individuals; privatisation and outsourcing of government contracts as part of the business-politicians relations; and extensive involvement in the corruption process of multinationals operating from rich and relatively corruption-free countries.

From the literature, several aspects of the essence of state capture can be discerned. Firstly, it is a problematic businessstate relationship rooted in the market for influence. Secondly, it is a deliberate and strategic choice made by new firms to give them a good chance of competing with incumbent firms. Thirdly, it focuses on the input or process side to making laws, policies, regulations and decrees, not the implementation side. Fourthly, the context of its occurrence is typically, but not exclusively, transitional or post-conflict countries. Fifthly, captors are typically private sector individuals or entities such as business persons, oligarchs, firms, institutions, criminal groups, and occasionally, public officials. Sixthly, the main targets of capture are formal state institutions such as parliament, legislature, judiciary, regulatory bodies, high-ranking public officials and politicians who play key roles in the formation of laws, policies, regulations and decrees. Further, means of state capture include illicit, non-transparent, formal or informal behaviour such as bribery or private payments. Finally, the main motive for capture is to subvert public interest by distorting laws, policies, regulations and decrees to achieve undue advantage or private gain.

\section{State capture situation in South Africa \\ Background}

The term 'state capture' is ubiquitous in South African political and social commentary and relates to two views (Chipkin 2016:1). The first is that of Thamm (2016a; 2016b; 2016c; 2016d) and Munusamy (2016a; 2016b), who use the term in referring to influence wielded by the Gupta brothers, President Zuma's friends, in allegedly appointing cabinet ministers, senior government officials and securing lucrative state tenders. The other view is expressed by Cronin (2016) and Shivambu (2016) for whom the term is used in the context of influence exerted by 'white monopoly capital' on government, particularly the Kebble and Rupert families. Thamm's view of state capture is widespread in South Africa, consistent with the traditional definition and the operating definition for the South African context in this article. Fakude (2016:n.p.) states that the so called state capture is nothing new in the South African political economy' and that 'the entire modern economy of South Africa is based on undue influence of business over politics and vice versa'. More poignantly, Chipkin (2016:1) argues that a conception of the state that has taken hold in the African context is that, increasingly, the state is becoming a vehicle for politicians and their cronies to 'get hold of the instruments and resources of the state and use them for their own purposes'.

The convergence of business interests and politicians through family ties, friendship and ownership of economic assets provides the platform for state capture in South Africa. The Gupta brothers' acknowledged friendship with the President and their ownership of lucrative tenders for coal supplies to Eskom, the power utility, has created tension between factions within the African National Congress (ANC), prompting the Deputy President to describe government as waging 'war with itself' (Georg 2016). The furore surrounding removal of Nhlanhla Nene as Finance Minister on 09 December 2015 and his replacement by Des van Rooyen ended when Pravin Gordhan replaced Van Rooyen on 14 December 2015. However, in a major cabinet reshuffle on 30 April 2017, Pravin Gordhan and Mcebisi Jonas were removed and replaced by Malusi Gigaba and Sfiso Buthelezi, respectively.

Claymore (2016) claims it has been the avowed policy of the ANC to capture the state in order to realise its own political and ideological interests which, according to Martin and Solomon (2016:24), has largely been achieved through seizure and control of all levers of the state except the Judiciary and possibly, Office of the Public Protector and the Independent Electoral Commission. Increasing centralisation of the economy has led to a situation where 'political power is seen as a mechanism that can be used to extract financial benefits from the state, and not necessarily to foster an environment where the needs of ordinary citizens are met' (Martin \& Solomon 2016:21-22). These authors further state that since 2009 there has been institutionalised capture of the economic and political segments of the state.

It is claimed the Gupta brothers have solid connections within the ANC and wide influence in its procedures and within the state (Martin \& Solomon 2016:24; citing Shivambu 2016) and that the benefits of their influence extends to three provincial premiers (The Free State, North-West and Mpumalanga), popularly called the 'Premier League', ministers and chief executive officers of state-owned enterprises (SOEs), the latter being targeted solely because they are the prime site for capturing tenders (Martin \& Solomon 2016:24). The Gupta brothers' ownership of lucrative tenders for coal supplies to Eskom, the state power utility, has created tension between 
factions within the ANC, prompting then the Deputy President (Cyril Ramaphosa) to describe government as waging 'war with itself' (Georg 2016).

\section{State of Capture Report (14 October 2016)}

The 'State of Capture Report' resulted from investigation by the Office of the Public Protector following complaints by the Dominican Order of Catholic Priests, Mr Mmusi Maimane (leader of the Democratic Alliance and leader of the Opposition in Parliament) and an anonymous person following media reports that Mr Mcebisi Jonas, then Deputy Minister of Finance, had been offered the position of Minister of Finance for a consideration of R600 000.00 in cash and a promise of R600 million in exchange for loyalty by one of the Gupta brothers at their Saxonwold home before then Minister of Finance, Mr Nhlanhla Nene, was dismissed on 09 December 2015.

The aftermath of Mcebisi Jonas' televised saga prompted the Public Protector to investigate various allegations on which the following observations, among others, were made:

- Regarding whether President Zuma improperly and in violation of the Executive Ethics Code, allowed members of the Gupta family and his son to be involved in the process of removal and appointment of the Minister of Finance in December 2015.

The Public Protector expressed concern on three issues: firstly, the Gupta brothers' possible awareness of Nhlanhla Nene's removal 6 weeks after Mcebisi Jonas had told him (Nene) about the Gupta's job offer in exchange for favours; secondly, Mr Van Rooyen's presence at the Guptas' home area (Saxonwold), at least, seven times before he was announced as Minister of Finance, including the day of announcement; thirdly, the fact that Nhlanhla Nene was actually removed after Mcebisi Jonas had told he would be removed. The Guptas' awareness of Des van Rooyen's appointment, if they were, would violate Section 2.3(e) of the Executive Ethics Code, which prohibits members of the executive from using confidential information outside their official duties. Additionally, failure of the President to verify Mr Nene's allegation of job offer by the Gupta brothers in exchange for favours could violate Section 34 of Prevention and Combating of Corrupt Activities Act (12 of 2004), which places a duty on people in positions of authority with knowledge of suspected offences to report to the police (State of Capture 2016:343-344).

- Regarding whether President Zuma improperly and in violation of the Executive Ethics Code, allowed a member of the Gupta family and his son to engage or to be involved in the process of removal and appointing various members of Cabinet.

According to the Public Protector, inaction in verifying Mabel Petronella ('Vytjie') Mentor's allegation of having been offered the position of Minister of Public Enterprises by the Gupta brothers violates Section 195 of the Constitution, and possibly, Section 2.3(c) of the Executive Ethics Code, which prohibits members of the executive from divulging confidential information acquired in their official capacity. Also, failure to verify Nhlanhla Nene's allegation of a job offer by the Gupta brothers in exchange for favours could violate Section 34 of Prevention and Combating of Corrupt Activities Act (12 of 2004), which places a duty on people in positions of authority with knowledge of suspected offence to report to the police (State of Capture 2016:344-345).

- Whether President Zuma improperly and in violation of the Executive Ethics Code, allowed members of the Gupta family and his son, to be involved in the process of appointing members of Board of Directors of SOEs.

Evidence supported the existence of a close relationship between Brian Molefe and the Guptas and circumstances surrounding the removal of Themba Maseko. The Public Protector expressed concern about nothing having been done to verify this relationship as required by Section 195 of the Constitution. Alleged involvement of the Gupta brothers and President Zuma's son, Duduzane Zuma, in appointing SOEs' boards of directors were backed by evidence, but no action had been taken despite a duty imposed by Section 195 of the Constitution (State of Capture 2016:345-346).

- Whether President Zuma has enabled or turned a blind eye, in violation of the Executive Ethics Code, to alleged corrupt practices by the Gupta family and his son in relation to allegedly linking appointments to quid pro quo conditions.

Other than the ANC and Parliament having considered investigating Mcebisi Jonas' allegations of having been offered a ministerial position in exchange for favouring the Gupta brothers, there was no evidence the executive took any action (State of Capture 2016:346).

- Regarding whether President Zuma and other Cabinet members improperly interfered in the relationship between banks and Gupta-owned companies, thus giving preferential treatment to such companies on a matter that should have been handled by independent regulatory bodies.

Cabinet's intervention in a private dispute between the banks and Oakbey, a company co-owned by the Gupta brothers and the President's son, was seen as unprecedented and could violate conflict of interest under Section 2.3(c) of the Executive Ethics Code and Sections 195 and 96(2)(b) of the Constitution (State of Capture 2016:346).

- Whether any state functionary in any organ of state or other person acted unlawfully, improperly or corruptly in connection with the appointment or removal of Ministers and Boards of Directors of SOEs.

The Board of Eskom was improperly appointed and did not conform to King III's report on good Corporate Governance, failed to act in the best interests of the country and no mechanisms existed to deal with actual or perceived conflicts 
of interest and the Minister of Public Enterprises did nothing to prevent conflicts of interest (State of Capture 2016:347-348).

- Whether any state functionary in any organ of state or other person acted unlawfully, improperly or corruptly in connection with the award of state contracts or tenders to Gupta linked companies or persons.

The Public Protector thought the conduct of the Minister of Mineral Resources regarding his flight itinerary to Switzerland was irregular and could violate the Public Finance Management Act (PFMA 1999), Section 9(2) of the Constitution and Section 2 of the Executive Ethics Act. Tegeta was unduly favoured regarding contracts awarded to it for supplying coal to Arnot Power Station, which enabled it to buy all Optimum Coal Mine (OCM) shares. Further, Tegeta did not fulfil all obligations to OCM, which was owed R437 870156.91 as of 31 August 2016, constituting possible violation of Sections 38 and 51 of the PFMA on prevention of fruitless and wasteful expenditure and could constitute misconduct. Eskom Board was found to have failed to exercise a duty of care (State of Capture 2016:348-349).

- Whether any state functionary in any organ of state or other person acted unlawfully, improperly or corruptly in connection with the extension of state provided business financing facilities to Gupta linked companies or persons.

Prepayment of R659 558079.00 to Tegeta purely to fund acquisition of all OCM shares did not conform to PFMA, showed lack of duty of care on the part of the Board, which could violate Section 50 of PFMA. Also, misrepresentations by Tegeta regarding the prepayment could be fraudulent. The handling of rehabilitation funds by the Bank of Baroda contravenes Section 24P of the National Environmental Management Act (NEMA) and Section 7 of the Financial Provisions Regulations: financial provision must be 'equal to the sum of the actual cost of implementing the plans and report contemplated in regulation 8 and regulation 11(1) for a period of at least 19 years forthwith' (State of Capture 2016:349-351).

Given the serious implications state capture has for South Africa, the Public Protector recommended that the President appoint a commission of inquiry within 30 days headed by a judge appointed by the Chief Justice to report its findings and recommendations to the President within 180 days. The President has taken the State of Capture Report for review and the case is set for October 2017.

\section{South African Council of Churches: 'Unburdening Panel Process Report' (18 May 2017)}

Following Mcebisi Jonas and 'Vytjie' Mentor's public allegations in 2016 about being offered ministerial positions by the Gupta brothers, the SACC set up a five-member panel consisting of Bishop Siwa, Justice Yvonne Mokgoro, Dr Brigalia Bam, Bishop Mosa Sono and Bishop Malusi Mpumlwana to work with a team of voluntary lawyers and researchers for public good using the gospel-inspired
SEE-JUDGE-ACT approach. The 'SEE' aspect of the approach involves rigorous research to fully understand the state of an issue under investigation and calls for collaboration with research entities such as the Human Sciences Research Council and Institute of Justice and Reconciliation. The 'JUDGE' dimension involves applying the gospel in order to arrive at a value judgement call on the issue, based on what is known; and the third, 'ACT', entails taking a resolution or principled position to act based on application of gospelinspired values. The decision is taken by a conference convened for that specific purpose.

The 'Unburdening Panel Process Report' states that 'South Africa may be inches away from a mafia state from which there could be no return ... a recipe for a failed state'. The report cites patterns of systemic undermining of governance beyond petty corruption with serious consequences for South Africa's constitutional democracy. It claims the existence of deliberately organised chaos to enable a power elite allegedly centred around President Zuma's exercise control over state systems through systematic siphoning of state assets achieved through:

- securing control over state wealth, through the capture of state-owned companies by chronically weakening their governance and operational structures;

- securing control over the public service by weeding out skilled professionals;

- securing access to rent-seeking opportunities by shaking down regulations to their advantage and to the disadvantage of South Africans;

- securing control over the country's fiscal sovereignty;

- securing control over strategic procurement opportunities by intentionally weakening key technical institutions and formal executive processes;

- securing a loyal intelligence and security apparatus; and

- securing parallel governance and decision-making structures that undermine the executive.

\section{'State Capacity Research Project Report': Betrayal of the Promise: How South Africa is being captured (25 May 2017)}

This report was released by an inter-university research partnership consisting of academics from four universities and their research teams: Centre for Complex Systems in Transition (University of Stellenbosch); Public Affairs Research Institute (University of the Witwatersrand); Development Policy Development Unit (University of Cape Town); a member of South African Research Chair programme on African Diplomacy and Foreign Policy (University of Johannesburg) and an independent journalist.

The main argument of this report is that South Africa has experienced a silent coup allegedly orchestrated by President Zuma and senior government officials that has removed the ANC from its place as the primary force for transformation in society (Bhorat et al. 2017). They collude with a network of corrupt brokers in a project aimed at repurposing state institutions to suit rent seekers' interest, thereby creating a 
'symbiotic relationship between the constitutional and the shadow state' (Bhorat et al. 2017:2). A constitutional state refers to 'the formalised constitutional, legislative and jurisprudential framework of rules that governs what government and state institutions can and cannot do', while a shadow state, according to Bhoral et al. (2017), is

the networks of relationships that cross-cut and bind together a specific group of people who need to act together for whatever reason in secretive ways so that they can either effectively hide, actively deny or consciously 'not know' that which contradicts their formal roles in the constitutional state. This is a world where deniability is valued, culpability is distributed (though indispensability is not taken for granted) and where trust is maintained through mutually binding fear. (p. 6)

Bhorat et al. (2017) claim the state capture situation arose from differences in strategy pursued by constitutional and radical reformers within the ANC. The constitutionalists believe in building state capacity to serve as the launching pad for fulfilling the equality and development promise of the new South Africa made in 1994. However, for radical reformers, subversion of constitutionally entrenched provisions is the route to fulfilling the promise. Essentially, it is a difference between gradual and accelerated or radical change between working in line with the constitution and going against it in an attempt to improve the material conditions of the majority of South Africans. Recognising the need to quickly improve living conditions for the majority of ordinary citizens, victory of the radical reformers at the 2007 Polokwane Conference and inspiration of the developmental state discourse is central to their repurposing SOEs. This is done in order to use their procurement systems as the primary mechanisms for rent-seeking at the interface between the constitutional and shadow state' (Bhorat et al. 2017:12) in the name of radical economic transformation. In the sections that follow, captor actors, capture targets and means or modalities of capture are described.

\section{Modus operandi of the patronage network Captor actors}

Bhorat et al. (2017:56-57) state that a formal and informal patronage network is involved in extracting and administering rents in the state capture situation in South Africa using the command and control model of 'war economy'. The structure the patronage network is said to be as follows: at the apex are controllers or patrons who secure access, maintain control over resources and dispense favours to competing elites. At the second level are elites responsible for 'establishing and maintaining patronage networks, which facilitate the distribution of benefits' (Bhorat et al. 2017:57), while entrepreneurs or brokers at the third level 'facilitate the movement of funds, information and/or goods both domestically and across transnational networks, and make use of "recruitment networks, lending networks, remittance networks and smuggling networks"' (Bhorat et al. 2017:57). Finally, the dealers, professional money-laundering syndicates based in Hong Kong, United Arab Emirates and other countries are responsible for moving money abroad.

\section{Areas or targets of capture}

Bhorat et al. (2017:2) state that the main targets of capture are PRASA, Eskom, Transnet and the National Treasury, which houses the Financial Intelligence Centre, Chief Procurement Office, Public Investment Corporation, boards of major development finance institutions and the guarantee system that allows SOEs 'to borrow from private lenders/banks without parliamentary oversight' in the name of radical economic transformation. The claimed actors in state capture have already centralised power in seven identifiable areas (Bhorat et al. 2017:):

- controlling SOEs by weakening their governance and operational structures, restructuring of SOE boards and exploiting the fact that SOE expenditures are not subject to the same degree of scrutiny as those of government departments as required by the Public Finance Management Act (1999);

- controlling the Public Service through the 2014 National Macro Organisation of State Project, which focused on operational details and highlighted the creation of a capable state to implement the National Development Plan, respond to challenges and speed up service delivery;

- securing access to rent-seeking opportunities by shaking down regulations: ministers, in collusion with private interests, arbitrarily use regulatory instruments or policy decisions to 'shake down' existing businesses, the TegetaGlencore Optimum deal being a prime example;

- securing control over the country's fiscal sovereignty: the National Treasury's Financial Intelligence Centre, which exposes illicit financial transactions, was the only intelligence unit not controlled by the network. The Treasury itself controls huge sums of money handled by the Industrial Development Corporation and Public Investment Corporation, all of which might be strong motivation for the removal of Pravin Gordhan and Mcebisi Jonas, who were obstacles;

- securing control over strategic procurement opportunities by intentionally weakening key technical institutions and formal executive processes;

- securing loyalty of the security and intelligence services: appointing loyalists to South African Revenue Service, the Hawks and the National Prosecuting Authority;

- securing parallel government and decision-making structures that undermine the executive, including strengthening of the 'Premier League': delegation of critical decisions to hand-picked groups in the form of unaccountable Inter-Ministerial Committees such as the Inter-Ministerial Group on Banks. (pp. 15-16)

\section{Means or modalities of capture}

'Repurposing' refers to 'the organised process of reconfiguring the way in which a given state institution is structured, governed, managed and funded so that it serves a purpose different to its formal mandate' (Bhorat et al. 2017:5). This process prepares target institutions not just for looting but also for 'consolidating political power to ensure longer-term survival, the maintenance of a political coalition, and its 
validation by an ideology that masks private enrichment by reference to public benefit' (Bhorat et al. 2017:5). According to the authors, SOE boards, including those of Eskom and Transnet, have been restructured to favour the interests of the Gupta family and their allies (Bhorat et al. 2017:12).

Bhorat et al. (2017:2) state that since 2012, a power elite has sought to centralise rent-seeking in order to squeeze out lower order rent-seeking competitors. Further, it is said that before the National Treasury came under the power elite control, consolidation of power to centralise rent-seeking had been achieved in five ways (Bhorat et al. 2017):

- bloating a politically compliant and dependent corps of top management in the public service;

- replacing good police and intelligence officers with loyalists agreeable to covering up rent seeking;

- SOEs' favouring Gupta and allies' network brokers in procurement process;

- establishing informally constituted elite 'kitchen cabinets' in place of the Cabinet as the primary decision-making body, resulting in usurping of executive authority;

- ensuring loyalty of National Executive Committee members through the Premier League. (p. 3)

Critical reading of the State of Capture, State Capacity Research Project and Unburdening Panel Process Reports suggests that the phenomenon of state capture exists in South Africa. However, what remains unknown is the number of ministers and government departments and the extent to which they have been, in one way or another, involved in siphoning state resources to benefit private individuals; the number and extent to which SOEs have been implicated; and the number, role and culpability of serving politicians, highranking public servants, members of boards of state enterprises involved and its impact on the country and citizens. This can only be clarified through a thorough, impartial judicial enquiry.

\section{Conclusion}

State capture, essentially parasitic plundering of public resources, poses a serious threat to the nascent South African democracy and needs to be taken seriously. Based on the typology of captured states outlined in ANC Today, South African state could be categorised as partially captured, which presents some hope of reversal. The main difficulty in combating state capture is that, as an aspect of administrative corruption, it is surreptitious and defies easy solutions. A zerotolerance approach to all types of corruption is the ultimate panacea. Additionally, adoption of strong reform measures aimed at buyers and sellers of influence and opening up policymaking processes is instructive. One area for reform is widening the market for influence by reducing powers of monopolies, removing anticompetitive advantages and promoting investment through incentives. Another is promoting access and transparency by involving relevant stakeholders' participation in formal policymaking processes through public hearings, corruption impact assessment procedures, e-government consultation or public comment mechanisms, oversight or consultative bodies and enhancing accountability of public officials responsible for individual specific regulations. Thirdly, strong regulatory and monitoring mechanisms governing political finance or funding are needed. Laws on conflict of interest, financial disclosure and asset declaration need to be strictly enforced, coupled with sensitising politicians and public officials through sustained public education and awareness campaigns. Finally, adjudication and award process for multi-million and multi-billion government tenders need to be reformed for transparency to be foregrounded and the phenomenon of 'tendepreneurship' discouraged. Above all, with a focus on advancing citizens' welfare and best interests, traditional African traditional governance offers a model for governance at the national level and being guided by the basics may be the best.

\section{Acknowledgements Competing interests}

The author declares that he has no financial or personal relationship(s) that may have inappropriately influenced him in writing this article.

\section{References}

Adams, G., Hayes, S., Weierter, S. \& Boyd, J., 2007, 'Regulatory capture: Managing the risk., A paper supporting a presentation within the stream of government regulators - The environment and the corruption risks it presents', Australian Public Sector Anti-Corruption Conference, Sydney, 24th October 2007.

ANC Today, 2016, "Is South Africa a "captured state"? The anatomy of a "captured state"', ANC Today, 25 May 2016, ANC Today, Online Voice of the African National Congress, viewed 24 August 2017, from http://anctoday.org.za/south-africacaptured-state-anatomy-captured-state/

Bardhan, P., 2001, 'The nature of institutional impediments to economic development', in S. Kahkonen \& M. Olson (eds.), A new institutional approach to economic development, pp. 245-267, Vistaar Publications, New Delhi.

Begović, B., 2005, Corruption, lobbying and state capture, CLDS Working Paper \#0106 March 2005, viewed 24 August 2017, from http://danica.popovic.ekof.bg.ac.rs/ 106.pdf

Bhorat, H., Buthelezi, M., Chipkin, I., Duma, S., Mondi, L., Peter, C. et al., 2017, Betrayal of the promise: How South Africa is being stolen, State Capacity Research Project, viewed 25 August 2017, from http://pari.org.za/wp-content/ uploads/2017/05/Betrayal-of-the-Promise-25052017.pdf

Campo, N.F. \& Giovannoni, F., 2006, Lobbying, corruption and political influence, IZA Discussion Paper No. 2313, September 2006, viewed 24 August 2017, from http:// ftp.iza.org/dp2313.pdf

Chipkin, I., 2016, The state, capture and revolution in South Africa, Working Paper, Public Affairs Research Institute (PARI), University of the Witwatersrand, Johannesburg.

Claymore, E., 2016, 'Africa is being re-colonised by the corrupt Mathews Phosa', The South African, 02 July, viewed 30 August 2017, from http://www.thesouthafrican. com/africa-being-re-colonised-by-the-corrupt-mathews-phosa/

Cronin, J., 2016, 'SACP: Neither the Oppenheimers, Ruperts, Koos Bekkers, nor the Guptas: Confront corporate state capture in all its manifestation, deal decisively with its immediate threats', Umsebenzi Online, 14 April, viewed 24 August 2017 from www.sacp.org.za/main.php?ID=5273

Evans, P., 1985, Embedded autonomy: States and industrial transformation, Princeton University Press, Princeton, NJ.

Fakude, T., 2016, State capture is not something new in South African political economy, viewed 22 August 2017, from http://www.thecitizen.in/index.php/ economy, viewed 22 August 2017, from http://www.thecitizen.in/index.php/ NewsDetail/index $/ 6 / 7487 /$
African-Political-Economy

Fazekas, M. \& Tóth, I.J., 2014, From corruption to state capture: A new analytical framework with empirical applications from Hungary, Working Paper Series: CRCB-WP2014:01, Corruption Research Centre, Budapest and Government Transparency Institute, Budapest.

Georg, C.-P., 2016, 'Why patronage and state capture spell trouble', The Conversation, 01 September, African Institute for Financial Markets and Risk Management, University of Cape Town, viewed 24 August 2017, from https://theconversation. com/why-patronage-and-state-capture-spell-trouble-for-south-africa-64704

Haggard, S., 1985, 'The politics of adjustment: Lessons from the IMF's Extended Fund Facility', International Organisations 39(3), 505-534. https://doi.org/10.1017/ S0020818300019160

Hall, D., 2012, Dealing with corruption and state capture, Public Services International Research Unit (PSIRU), Business School, University of Greenwich, London. 
Hellman, J.S., n.d., 'Strategies to combat state capture and administrative corruption in transition economies', in Background paper prepared for the conference: Economic reform and good governance: Fighting corruption in transition countries, Sponsored by the Graduate School of Public Policy and Management of Qinghu University and Carnegie Endowment for International Peace, April 11-12, Qinghua University, Beijing, China.

Hellman, J.S., Jones, G. \& Kaufmann, D., 2000a, Seize the state, seize the day: State capture, corruption and influence in transition, Policy Research Working Paper capture, corruption and influence in transition, Policy Research Working Paper Working Paper No. 2444, Pp. 1-11, The World Bank, World Bank Institute: Governance, Regulation and Finance Division, Europe and Central Asia Region Public Sector Group and European Bank of Reconstruction and Development, Office of the Chief Economist.

Hellman, J.S., Jones, G. \& Kaufmann, D., 2000b, 'Seize the state, seize the day: An empirical analyses of state capture and corruption in transition', Paper prepared for the ABCDE Conference, Washington, DC, 18-20th April.

Hellman, J.S., Jones, G., Kaufmann, D. \& Schankerman, M., 2000c, Measuring governance and state capture: The role of bureaucrats and firms in shaping the governance and state capture: The role of buneaucrats $\mathrm{M}$. Working Paper No 51, The Business Environment and Enterprise (BEEPS), viewed 30 August 2017, from http://www.ebrd.com/downloads/research/economics/ 30 August 2017, from http:/
workingpapers/wp0051.pdf

Hellman, J. \& Kaufmann, D., 2001, 'Confronting the challenge of state capture in transition economies', Finance and Development Magazine 38(3), 5-8.

Innes, A., 2013, The political economy of state capture in Central Europe, JCMS Journal of Common Market Studies 52(1), 88-104. ISSN 0021-9886. https://doi. org/10.1111/cms.12079

Kupferschmidt, D., 2009, Illicit political finance and state capture, International Institute for Democracy and Electoral Assistance (IDEA), Stockholm, viewed 24 August 2017, from http://www.idea.int/resources/analysis/upload/IDEA Inlaga_low.pdf

Martin, M.E. \& Solomon, H., 2016, 'Understanding the phenomenon of "state capture" in South Africa', Southern African Peace and Security Studies 5(1), 21-35.

Mtimka, O., 2016, 'Why state capture is a regressive step for any society', The Conversation, viewed 25 August 2017, from https://theconversation.com/whystate-capture-is-a-regressive-step-for-any-society-56837

Munusamy, R., 2016a, 'Captura continua: Guptas triumph as ANC shuts down state capture probe', Daily Maverick, 01 June, pp. 13-14.

Munusamy, R., 2016b, 'Get Guptas, duck Zuma: SACP's obstacle race on state capture', Daily Maverick, 06 June, viewed 24 August 2017, from https://www. dailymaverick. co.za/article/2016-06-06-get-guptas-duck-zuma-sacps-obstacle-race-on-stateco.za/article
capture/

Ouzounov, N.A., 2004, 'Facing the challenge: Corruption, state capture and the role of multinational business, 37 J. Marshall L. Rev. 1181', The John Marshall Law Review 37, 4.

Pesic, V., 2007, State capture and widespread corruption in Serbia, Centre for European Policy Studies (CEPS) Working Document No. 262/March 2007, viewed 23 August 2017, from http://aei.pitt.edu/11664/1/1478.pdf

Philp, M., 2008, 'Peacebuilding and corruption', International Peacekeeping 15(3) 310-327. https://doi.org/10.1080/13533310802058786

Richter, S., n.d., Der erkaufte Frieden: Welche Ordnung schafft 'state capture' in Nachkriegsgesellschaften? The 'Untouchables': State capture in post-conflict countries, viewed 25 August 2017, from http://www.afk-web.de/fileadmin/afk web.de/data/zentral/dokumente/AFK-Kolloquium_2016/Paperroom_2016/ Paper_AFK_Solveig_Richter.pdf
Robison, R. \& Hadiz, V.R., 2004, Reorganizing power in Indonesia: The politics in and of markets, Routledge Curzon, London.

Santos, E.G., 2011, Impact on the state through state capture: Development of the state capture concept based on cases of some countries in Latin America, Vortex Working Paper No. 2, Vortex Foundation, Bogotá.

Shivambu, F., 2016, 'State capture: It's criminal and it is nothing new', Daily Maverick, 28 March, viewed 30 August 2017, from https://www.dailymaverick.co.za/ opinionista/2016-03-24-state-capture-its-criminal-and-it-is-nothing-new/\#. WSGTejtOWHo

Sitorus, L.E., 2011, 'State capture: Is it a crime? How the world perceived it', Indonesia Law Review 1(1), 45-68. https://doi.org/10.15742/ilrev.v1n2.82

South Africa, 1998, Executive Members' Ethics Act (No 82 of 1998), Government Printer, Pretoria.

South Africa, 1999, Public Finance Management Act (No 1 of 1999), Government Printer, Pretoria.

South Africa, 2016, State of capture: A report of the Public Protector, Report No: 6 of 2016/17, 14 October 2016, Public Protector South Africa, Pretoria.

Southern African Council of Churches, Unburdening Panel Report, viewed 30 June 2017, from http://sacc.org.za/news/sacc-report-church-public-unburdeningpanel-process-regina-mundi-church-soweto-may-18-2017/

Srouji, S., 2005, Capturing the state: A political economy of Lebanon's public debt crisis 1992-2004. A research paper presented in partial fulfillment of the requirements for obtaining the degree of Master of Arts in Development Studies in Internationa Political Economy, Institute of Social Studies, The Hague, The Netherlands.

Stigler, G.J., 1971, 'The theory of economic regulation', The Bell Journal of Economics and Management Science 2(1), 3-21. https://doi.org/10.2307/3003160

Thamm, M., 2016a, 'State capture: Did the Guptas offer treasury's top job to Deputy Minister Jonas?' Daily Maverick, 10 March, viewed 30 June 2017, from https:// www.dailymaverick.co.za/article/2016-03-10-state-capture-did-the-guptas-offertreasurys-top-job-to-deputy-minister-mcebisi-jonas/

Thamm, M., 2016b, 'State capture: The floodgates open as Deputy Finance Minister Jonas admits Guptas offered him top job', Daily Maverick, 16 March, viewed 30 June 2017, from https://www.dailymaverick.co.za/article/2016-03-16-state capture-the-floodgates-open-as-deputy-minister-jonas-admits-guptas-offeredhim-top-job/

Thamm, M., 2016c, 'State capture: Banking and business screws on the Guptas tighten considerably', Daily Maverick, 07 April, viewed 30 June 2017, from https://www. dailymaverick.co.za/article/2016-04-07-state-capture-banking-and-businessscrews-on-the-guptas-tighten-considerably/

Thamm, M., 2016d, 'State capture: Thuli's final quest for the truth - Investigating the Guptas' political influence', Daily Maverick, 08 July, viewed on 30 June 2017, from https:/www.dailymaverick.co.za/article/2016-07-08-state-capture-thulis-finalquest-for-the-truth-investigating-the-guptas-political-influence/

Transparency International, 2014, State capture: An overview, Anti-Corruption Helpdesk, viewed 28 August 2017, from https://www.law.kuleuven.be/icr/ integriteit/egpa/previous-egpa-conferences/malta-2009/matei.pdf

Varraich, A., 2014, Corruption: An umbrella concept, Working Paper Series 2014:04, The Quality of Government Institute, Department of Political Science, University of Gothenburg, Goteburg.

Wren-Lewis, L., 2011, 'Regulatory capture: Risks and solutions', in A. Estache (ed.), Emerging issues in competition, collusion and regulation of network industries, pp. 147-169, Centre for Economic Policy and Research, London. 